Warszawskie Studia Pastoralne UKSW

Rok XII 2017 Nr 1(34)

Danuta Stasiak

\title{
ZNACZENIE MARYI W POLSKIM KOŚCIELE A PRYMASOSTWO KARDYNAŁA STEFANA WYSZYŃSKIEGO
}

The importance of Mary in the Polish Church and the primacy of Cardinal Stefan Wyszynski

Żyjemy w czasach kryzysu wartości. Wciąż z większą siłą rozpowszechniają się postawy takie, jak: egoizm, praktyczny materializm, konsumpcjonizm, oportunizm i ateizm. Pokolenie wychowane w takich wartościach nie sprosta wyzwaniom czasów i nie zbuduje nowej Polski szczęśliwych ludzi. Do przemiany wzywał już Wielki Prymas Tysiąclecia. Prosił, by zacząć od siebie: „Nie trzeba oglądać się na innych - mówił - na tych lub owych, może na polityków, żądając od nich, aby się odmienili. Każdy musi zacząć od siebie. A wtedy, gdy wszyscy będziemy się odradzać, i politycy będą musieli się odmienić, czy będą chcieli, czy nie""1.

„Między tymi dwoma skrajnościami - chwała człowieka za cenę śmierci Boga lub chwała Boga za cenę zanegowania człowieka - sytuuje się wiara Kościoła, podtrzymująca właśnie gorszącą równowagę dogmatu chrystologicznego" - podkreśla w znakomitej pracy "Maryja ikoną tajemnicy” abp Bruno Forte - włoski duchowny katolicki. W Maryi należy odczytać znaczenie ikony, tzn. figury, która jak najściślej kieruje nas do transcendencji Boga, wkraczającej w immanentność świata. Forte określa tę sytuację, nazywając Maryję ikoną Tajemnicy, ikoną Syna, chodzi bowiem o wydarzenie zaistniałe

1 S. Wyszyński, Z homilii wygłoszonej 2 lutego 1981 w Gnieźnie, www.nonpossumus. pl/nauczanie/1005.php (dostęp: 10.10.2016 r.). 
między Bogiem a człowiekiem². Bóg stawia Maryję na właściwym Jej miejscu, przez siebie wyznaczonym.

Osobliwe towarzyszenie Maryi Kościołowi współcześnie odnawia jego żywotność w zaangażowaniu się w proces nowej ewangelizacji. Rysuje się wyraźny sens współpracy Kościoła z Maryją. „Polska musi pozostać i pozostanie wierna Chrystusowi Królowi i pod opieką Matki Najświętszej”3. Pobożność Prymasa A. Hlonda miała wielki wpływ na teologię S. Wyszyńskiego. Maryjne czasy Augusta Hlonda charakteryzowały się takimi elementami, jak: objawienia Matki Bożej, sanktuaria i wyrażający się w nich kult, uwydatniony w pieśniach, modlitwach i nabożeństwach. „(...) Polska pieśń maryjna stanowi frapujący temat, który zasługuje na wieloaspektowe ujęcie. Przede wszystkim z punktu widzenia teologicznego, duszpasterskiego i literackiego $(\ldots)^{4}$. Pieśni te śpiewano $\mathrm{w}$ czasie liturgii $\mathrm{z}$ okazji świąt maryjnych, podczas okolicznościowych nabożeństw, w domach, przy pracy, w polu, w czasie podróży, rano i wieczorem. Rósł i wzmacniał się kult maryjny. „W Tobie ufność, Maryja! - Można powiedzieć, że na tym opierała się „teologiczna formacja” A. Hlonda, S. Wyszyńskiego i K. Wojtyły. Maryja jest figurą Kościoła - Mater Ecclesiae ${ }^{5}$.

2 Por. B. Forte, Maryja, ikona Tajemnicy. Zarys mariologii symboliczno-narracyjnej. Warszawa 1999, s. 171.

3 A. Hlond, W służbie Boga i Ojczyzny. Wybór pism i przemówień 1922-1948, red. St. Kosiński, Warszawa 1988. s. 69

4 J. Buczek, Bóg Ojciec a Maryja w pieśniach zamieszczonych w Śpiewniku kościelnym ks. J. Siedleckiego, w: „Salvatoris Mater” 1999, nr 3, s. 81.

${ }^{5}$ Memoriał biskupów polskich, wyjaśniając znaczenie tytułu, sięga po pisma Ojców Kościoła, autorów średniowiecza oraz po niektóre dokumenty. Magisterium Ecclesiace. Memoriał Episkopatu Polski do Ojca Świętego Pawła VI w sprawie ogłoszenia Maryi Matka Kościoła i oddania Jej świata podczas obrad Soboru Watykańskiego II (Jasna Góra, 4 IX 1964 r.), w: Matka Odkupiciela Matką Kościoła, wybór i oprac. Instytut Prymasowski Ślubów Narodu, Warszawa 1990. 


\section{Rola Maryi w Bożej ekonomii zbawienia}

Kościół zaczyna się od Matki Bożej, która prowadzi nas do zbawienia ${ }^{6}$. „Wszystko na tej ziemi zaczyna się przez Maryję”7. Można też mówić o macierzyństwie Maryi dla Kościoła Mistycznego Ciała Chrystusa $^{8}$. To aspekt macierzyństwa chrystologicznego i eklezjalnego, gdy Maryja przyjmuje zwiastowanie $($ Mt 1, 19) i wchodzi w krąg społeczności Kościoła (Łk 1, 28 ). Ona przez wiarę przyjmuje Jezusa. Z szeregu ludzi została powołana do współpracy z Bogiem. Dzięki wolnej współpracy dokonuje się zbawienie. Od pierwszych wieków Kościoła Maryję nazywamy nową Ewą. Wielu Ojców i doktorów Kościoła widzi ponadto w Niewieście zapowiedzianą przez „Protoewangelię" Matkę Chrystusa, Maryję jako „nową Ewę”. Ona była Tą, która jako pierwsza została zachowana od wszelkiej zmazy grzechu pierworodnego ${ }^{9}$, a w czasie całego swego życia ziemskiego nie popełniła żadnego grzechu (por. KKK 441). Najświętsza Maryja Panna, która najgodniej ze wszystkich stworzeń umiała przyjąć Chrystusa, prowadzi nas prostą drogą do Niego ${ }^{10}$. Jest więzią łączącą Chrystusa z Kościołem - wchodzi w działalność publiczną Chrystusa - Kościoła.

${ }^{6}$ Por. Łk 1, 38; KKK 65.

7 S. Wyszyński, Maryjność Wielkiej Nowenny. Przemówienie Stefana Kardynała Wyszyńskiego do Duszpasterzy Sanktuariów Maryjnych z 11 maja 1959 r., w: Głos Jasnej Góry, Warszawa 1984, s. 97; KP 5, s. 219.

8 Dogmat „O Bożym Macierzyństwie Maryi” został ogłoszony na Synodzie w Efezie w 431 r. (święta Dziewica jest Matką Boga ponieważ według ciała porodziła Słowo Boże, które ciałem się stało).

9 Dogmat „O Niepokalanym Poczęciu Maryi” został ogłoszony w 1854 r. przez papieża Piusa IX. (Najświętsza Maryja Panna w pierwszej chwili swego poczęcia za szczególną łaską i przywilejem Boga Wszechmogącego, przez wzgląd na zasługi Jezusa Chrystusa, Zbawiciela rodzaju ludzkiego, została zachowana wolna od wszelkiej zmazy winy pierworodnej.); zob. Pius IX, Ineffabilis Deus. O Niepokalanym Poczęciu Najświętszej Maryi Panny, Niepokalanów 2003; Maria Immaculata. 150 rocznica ogłoszenia dogmatu o Niepokalanym Poczęciu NMP, red. J. Marecki, L. Rotter, Kraków 2004.

10 Biblijny kontekst kierunku Ad Mariam per Iesum znajduje się podczas wydarzeń w Kanie Galilejskiej (J 2, 1, 11); zob. J. Nowak, Maryja w liturgii i pobożności Kościoła, Poznań 2009, s. 165-168. 
Kościół czci Maryję jako dziewicę bez grzechu ${ }^{11}$. Pius XII stwierdza, że Maryja nie uległa zepsuciu w grobie, ale w pełni z duszą i ciałem jest uwielbiona w niebie ${ }^{12}$. Zagadnienie pełnej świętości Maryi, jako jeden z pierwszych, poruszył w IV wieku św. Epifaniusz z Salaminy. Chrystus musiał narodzić się z Maryi Dziewicy, gdyż tak mówiło o Mesjaszu proroctwo $(\mathrm{Iz} 7,14)^{13}$. Ta, która uwierzyła i całkowicie zaufała Bogu, stała się dla całej ludzkości początkiem nowego życia Matką Odkupiciela (RM 2) ${ }^{14}$. Maryja od początku wchodzi w krąg społeczności Kościoła ${ }^{15}$. Św. Jan przypisuje Matce Maryi (św. Annie) inicjatywę podjęcia przez Jezusa działalności publicznej. Maryja stała pod Krzyżem. Jezus powiedział do Matki: „Niewiasto, oto Twój Syn”"16. Jezus przekazuje Maryi funkcje Matki - wszystkich. Maryja z Matki Jezusa awansowała na Matkę Boga. Zanim Kościół stał się Piotrowy, od początku był już maryjny. Ona udziela łask, decyduje o zbawieniu, ponieważ jest Matką wszystkich. Maryja jest miłosierdziem - jako

\footnotetext{
11 Dogmat „O Maryi zawsze Dziewicy” ogłoszony został na Synodzie Laterańskim w Rzymie w 649 r. przez papieża Marcina I (Ona poczęła bez nasienia, przez Ducha Świętego... i bez naruszenia porodziła Go... i po Jego urodzeniu zachowała swe nienaruszone dziewictwo).

12 Dogmat „O wniebowzięciu Najświętszej Maryi Panny” ogłoszony został w 1950 r. przez papieża Piusa XII (Niepokalana Boża Rodzicielka, zawsze Dziewica, Maryja, po wypełnieniu życia ziemskiego, została z ciałem i duszą do chwały niebieskiej wzięta.).

13 Por. Maria Immaculata: 150. rocznica ogłoszenia dogmatu o Niepokalanym Poczęciu NMP, dz. cyt., s. 162-170.

14 Jan Paweł II w Redemptoris Mater odwoływał się do bogatej tradycji Kościoła (RM 48), dokonując analizy testamentu Chrystusa przekazanego z krzyża. Papież mówił: „Jak wiemy, Maryja otrzymała w ekonomii zbawienia najzupełniej szczególne miejsce: jest Ona również, jak i my, członkiem Kościoła, jest także odkupiona przez Chrystusa; jest zatem naszą Siostrą. Ale właśnie z racji jej wyniesienia do godności Matki Odkupiciela wszystkich ludzi i dlatego, że jest doskonałą, a dostojną przedstawicielką całej ludzkości mamy pełne prawo nazywać Maryję Matką nas wszystkich (w znaczeniu typicznym), a zwłaszcza Matką naszą - nas wierzących i odkupionych, Matką Kościoła, Matką wiernych.”

15 Por. Łk 1, 28.

16 Łk 26-27.
} 
Matka Kościoła przejmuje funkcje Ducha Świętego ${ }^{17}$. Maryja okazuje nam, że jest tą oczekującą, pokazuje nam, że powinniśmy wzorować się na Niej, na Jej życiu w przygotowaniu na paruzję ${ }^{18}$. Apostolstwo w Kościele jest koniecznym następstwem oddania się Niepokalanej. Dlatego prymas August Hlond 8 września 1946 r. poświęcił Polskę Niepokalanemu Sercu Maryi ${ }^{19}$. Akt ten był wypełnieniem żądania wyrażonego przez Matkę Bożą w Fatimie ${ }^{20}$. „Zwycięstwo ma przyjść przez Maryję - jak w zwycięstwie nad wojskami tureckimi pod Lepanto w 1571 r." ${ }^{21}$ Jak przyjdzie zwycięstwo, to tylko przez Maryję ${ }^{22}$. To „Jasna Góra jest stolicą Maryi, przez Maryję przyszedł Syn Boży by zbawić świat i tu również przez Maryję przyjdzie zbawienie dla Polski”23. „Nie bójmy się, że Maryja przesłoni nam Chrystusa. Ona jest po to, aby do Niego prowadzić. Nie lęka się Jej cała Trójca Święta, bo „Chwała Ojcu i Synowi i Duchowi Świętemu, jak była na początku, teraz i zawsze i na wieki wieków” - w Niej i przez Nią"24. Maryja, jako miłosierna Matka, która jest Serca Jezusowego uosobieniem, której jedynym celem jest przebaczać i prowadzić grzeszników do Swojego Syna - Chrystusa Króla. Możemy ją nazwać duchową Matką wszystkich ludzi. Tą, która wspomaga Kościół (jest Matką Kościoła), która jest Wspomożycielką, Orędowniczką i Pośredniczką łask Bożych. Maryja nosi w sobie „majestat łaski” (RM 11) i uczestniczy w dziele

\footnotetext{
17 Por. S. Wyszyński, Nadzieja na oddanie świata Matce Kościoła (Warszawa, 11.06.1973 r.), nr 1238, s. 3 i 5.

18 Por. D. Mastalska, Maryja wzorem i nauczycielka w nauczaniu Jana Pawła II, „Salvatoris Mater” 2003, nr 3, s. 90-104.

19 Zob. A. Hlond, W stużbie Boga i Ojczyzny, dz. cyt.

20 Pius XII w 1942 r. uznał orędzie fatimskie za prawdziwe i nazwał żądania Najświętszej Maryi Panny „jedynym ratunkiem świata”. Zob. R. Brzezińska, Ku zwycięstwu. Rzecz o kardynale Auguście Hlondzie, Ząbki 2004, s. 112-131.

21 Pius V wprowadził święto na ten dzień Matki Bożej Różańcowej; zob. J. Nowak, Maryja w liturgii i pobożności Kościoła, Poznań 2009.

22 Por. A. Hlond, W stużbie Boga i Ojczyzny, dz. cyt., s. 60-79.

${ }^{23}$ Akt ten równocześnie jest wypełnieniem prośby Nieba o Intronizację Serca Jezusowego. Zob. K. Z. Dobrzycki, Dziecko Boże Rozalia Celakówna, t. 3, Skawina 2005, s. 39.

24 Tamże, s. 107-108.
} 
odkupienia przez wiarę. „Maryja stała na kościele z jego północnej strony i opiekuńczo rozpościerała nad nim swój płaszcz"25. Wizja ta mówi nie tylko o Polsce. Aby uratować świat, „trzeba przeprowadzić Intronizację Najświętszego Serca Pana Jezusa we wszystkich państwach i narodach na całym świecie".

Prymas Hlond uważał, że przez intronizację nastąpi „odnowienie serc" ${ }^{26}$. Polska stanie się wówczas prawdziwym Królestwem Maryi i światową potęgą, o czym daje świadectwo prorok Zachariasz (12, 1-4): „Brzemię słowa Pańskiego na Izraela. Mówi Pan, rozciągający niebiosa i gruntujący ziemię, a tworzący ducha człowieczego w nim: Oto Ja stawię Jeruzalem naprożnikiem obżarstwa wszystkim narodom wokoło (...)”. Królestwo Maryi czyli Polska! To bardzo znaczące słowa. Nikt, jak Maryja, nie może być wsparciem i przewodnikiem do Chrystusa w przygotowaniu Kościoła do macierzyńskiej współpracy Bogarodzicy z dziełem zbawienia w Chrystusie Panu (por. RM 49). Maryja jest obecna w pielgrzymującym narodzie przez wiarę; jest wzorem nadziei ${ }^{27}$.

\section{Wiara w maryjną tożsamość narodową}

Jak wiemy, wiara jest łaską. Oddanie się Maryi, stając się formą życia chrześcijańskiego, wpisuje się więc w perspektywę łaski. Wniebowzięcie Matki Bożej „z ciałem do nieba” jest główną treścią wiary. W dniu Wniebowzięcia Najświętszej Marii Panny spotykają się na Jasnej Górze setki tysięcy osób, niekiedy nawet ponad milion. Wniebowzięcie NMP to jedno z głównych świąt maryjnych obchodzonych

\footnotetext{
${ }^{25}$ Zob. A. K. Emmerich, Żywot i Bolesna Męka Pana Naszego Jezusa Chrystusa i Najświętszej Matki Jego Maryi wraz z Tajemnicami Starego Przymierza według widzeń błogosławionej Anny Katarzyny, t. 1, Wrocław 2005, s. 28-79; https://katolikintegralny.wordpress.com/2016/01/09/papiestwo-w-wizjach-katarzyny-emmerich-oraz-marie-julie-jahenny/ (dostęp: 30.07.2016 r.).

26 R. Celakówna, Wyznania z przeżyć wewnętrznych, red. W. Kubik, Kraków 2007, s. 278.

27 Por. Jan Paweł II, Redemptoris Mater. Encyklika o Błogosławionej Maryi Dziewicy w życiu pielgrzymującego Kościoła, Wrocław 1995, nr 42.
} 
uroczyście aż do dziśs ${ }^{28}$. Max Weber, wybitny niemiecki filozof oraz teoretyk, twierdzi, że naród jest wspólnotą duchową i emocjonalną, a tożsamość narodowa jest ważna ${ }^{29}$. Tożsamości Polski jest miejscem, gdzie kształtowały się jej dzieje. Polska jest Maryjna od zarania. Gdy chrystianizacja weszła na dobre do Polski w XI w., rozwijał się już kult do Matki Bożej Niepokalanej - przewodniczki w drodze do zbawienia. Pierwsze polskie świątynie budowano pod wezwaniem Matki Bożej. Pierwsza, wzniesiona w Gnieźnie, otrzymała wezwanie Wniebowzięcia Najświętszej Maryi Panny ${ }^{30}$. Pierwszy zaś utwór napisany w języku ojczystym, to Bogurodzica. Pieśń stała się hymnem narodowym i modlitwą, z którą rycerze wyruszali do boju. Bogurodzicę śpiewano nie tylko przed bitwą, lecz umieszczano jej tekst na początku statutów, polecając w ten sposób opiece Maryi powodzenie orężne i porządek społeczny ${ }^{31}$. U schyłku średniowiecza i na początku polskiego renesansu pobożność maryjna została ugruntowana ostatecznie. Uczestniczą w niej wszystkie warstwy społeczne, o czym mówią dzieje Polski na Jasnej Górze. W połowie XV wieku w Polsce powszechny był kult obrazu jasnogórskiego, który nawet przekraczał polityczne i etniczne granice ówczesnej Polski ${ }^{32}$. Jasna Góra była centrum religijności polskiego średniowiecza. Dokument Translatio... ${ }^{33}$ podaje okoliczności przybycia cudownego obrazu do Polski, który

\footnotetext{
28 Około 650 r. w Rzymie było już święto, którego przedmiotem celebracji stał się koniec ziemskiego życia Maryi. Zob. J. Nowak, Maryja w liturgii i pobożności Kościoła, dz. cyt.

${ }^{29}$ Zob. A. Wolska, Max Weber - recenzja, Warszawa 1999.

30 Najstarsza rotunda w Gnieźnie nosiła imię Najświętszej Maryi Panny. Kluczową rolę Gniezna (przede wszystkim religijną) w państwie pierwszych Piastów potwierdza także fakt złożenia tam szczątków św. Wojciecha oraz ustanowienia w nim centrum administracji kościelnej po przyjęciu chrześcijaństwa.

31 Wyrazem jej jest najstarsza pieśń religijna, spełniająca w pewnym okresie funkcje pieśni narodowej - Bogurodzica, której autorstwo przypisywane było św. Wojciechowi. Niektórzy z historyków dopatrują się wyraźnych wpływów bizantyjskich. Zob. J. Nowak, Maryja w liturgii i pobożności Kościoła, dz. cyt., s. 176-196.

${ }^{32}$ Dokumentuje to Jan Długosz.

33 Oryginał pergaminowy dokumentu z aktem fundacji Jasnej Góry przez Władysława Opolskiego z 1382 r. zachował się do dziś w bibliotece klasztornej.
} 
zasłynął tu licznymi łaskami ${ }^{34}$. Popularność Jasnej Góry cieszyła katolików polskich z dworem królewskim i hierarchią na czele. Kult obrazu Matki Boskiej Częstochowskiej jako palladium narodowe został ugruntowany w świadomości narodu już w pierwszej połowie wieku XVII, co uznaje się za zasługę dynastii Wazów. Pierwsza polska koronacja, przeprowadzona na Jasnej Górze, miała „charakter uroczystości ogólnopaństwowej"35.

Jasna Góra z cudownym obrazem Czarnej Madonny, czczonej jako Królowa Polski, stała się duchową stolicą kraju ${ }^{36}$. Najświętsza Maryja Panna wstawiała się u Boga za polskim narodem. Maryja wyprosiła wielkie zwycięstwo pod Grunwaldem w 1410 r. Przed bitwą król Władysław Jagiełło i rycerstwo polskie leżeli krzyżem przed obrazem Maryi, a walkę zaczęli śpiewem Bogurodzica. Po zwycięstwie Jagiełło, jako wotum, ozdobił Obraz Jasnogórski złotą blachą z promieniami dookoła głowy, wyrażając w ten sposób swoje przekonanie, że Maryi zawdzięcza pokonanie wroga. W 1655 r. Matka Boża obroniła nas przed Szwedami - zwycięska obrona, po dowództwem przeora o. Augustyna Kordeckiego, zakończona 27 grudnia tegoż roku, przeszła do historii jako cudowna interwencja Boga za sprawą Maryi ${ }^{37}$. W 1683 r. król Jan Sobieski odniósł zwycięstwo nad Turkami pod Wiedniem za pośrednictwem Matki Bożej. 15 sierpnia 1920 r., w Uroczystość Wniebowzięcia Najświętszej Maryi Panny, wojska rosyjskie zostały rozgromione. Uznano to za cud nad Wisłą za sprawą Matki Bożej. Maryjność nabiera szczególnej wagi w ekonomii apostolstwa chrześcijańskiego, ponieważ zawsze broni narodu polskiego. Dla katolików był on objawieniem, w którym identyfikują się modlitwy i pobożność

\footnotetext{
34 Zob. J. Tomziński, Z. Modzelewski, D. Szumska, Panno Święta, co Jasnej bronisz Częstochowy, red. J. Tomziński, Z. Modzelewski, D. Szumska, Paryż 1981.

35 Zob. Koronacje papieskie Wizerunków Matki Bożej według kolejności ogłoszenia, www.katolik.pl (dostęp: 06.04.2016 r.).

36 Por. S. Jabłoński, Wokół koronacji Cudownego Obrazu diademami św. Piusa X, w: Z Maryja Królową Polski bądźmy świadkami miłości. Dziś i jutro, Jasna GóraCzęstochowa 2010, s. 119.

37 Por. Cz. Ryszka, Jubileusz zwycięskiej obrony Jasnej Góry: 350-lecie potopu, „Niedziela” 2004, nr 49, s. 8.
} 
wielu pokoleń. Maryja kształtowała poczucie tożsamości narodowej. Rozwój rangi i funkcji Częstochowy pojmowany był jako symbol zespołu pewnych wartości, wzorów i postaw osobowych, wchodzących do kultury narodowej, które najlepiej są widoczne w dziejach literackich i twórczości plastycznej, powstających z inspiracji paulińskiej. Powstała w tych czasach niesłychana ilość literatury maryjnej. Gorące uczucia, jakie Polacy zawsze żywili do Matki Bożej, znajdowały swój wyraz w poezji. Powstały wiersze, pieśni o wysokiej wartości artystycznej, a także proste rymy. Poezja ta rozkwitła szczególnie po obronie Jasnej Góry i za czasów konfederacji barskiej. Autorzy łączyli w niej kult Matki Bożej z losami narodu polskiego. Polska poezja romantyczna wyróżniała się duchem prawdziwie chrześcijańskim na tle twórczości innych narodów. Wyraża ona głębię uczuć religijnych i patriotycznych, ale też często przybiera charakter błagalnej modlitwy o niepodległość, a nawet proroctwa. Adam Mickiewicz wołał do Maryi w inwokacji do Pana Tadeusza: „Panno Święta, co Jasnej bronisz Częstochowy i w Ostrej świecisz bramie!” Juliusz Słowacki miał na myśli Bogurodzicę z Jasnej Góry, kiedy każe wybierającemu się pod Częstochowę Kazimierzowi Pułaskiemu przez o. Marka modlić się i ułożył na cześć Królowej nie jedną strofę ${ }^{38}$. Historia Sanktuarium Jasnogórskiego była także natchnieniem dla pisarzy okresu pozytywizmu, np. Potop Henryka Sienkiewicza czy Kordecki Józefa Ignacego Kraszewskiego. Do tych samych wydarzeń nawiązywał Stanisław Wyspiański - Śluby Jana Kazimierza. Władysław Reymont pięknie opisał przeżycia pątników pieszej pielgrzymki warszawskiej w czternasto-reportażach drukowanych w Tygodniku Ilustrowanym. Cudowny obraz Jasnogórski to także bardzo częsty temat twórczości artystycznej - plastycznej. Matkę Bożą malowali na swych obrazach: Jan Matejko, Artur Grottger, Józef Chełmoński, Piotr Stachiewicz, Henryk Rodakowski, January Suchodolski, Elwir Andriolli i inni.

\footnotetext{
38 W latach 1809-1849 napisał: „Boga Rodzico Dziewico! Niegdyś królowie Korony swoje składali, a potem Tyś je zwracała, jakby nowem były złotem (...). Zob. K. Wojtkiewicz, Maryjny wzorzec odnowy wiary narodu polskiego wedtug Prymasa Stefana Wyszyńskiego, „Rocznik Skrzatuski” 2013, t. I, s. 35.
} 
Stanisław Moniuszko skomponował na Jej cześć hymny, pieśni i inne utwory muzyczne. Obraz został uznany za relikwię Królestwa Polskiego. Stał się narodowym symbolem, niemal drugim narodowym godłem. Zawsze miał go przed sobą sługa Boży Prymas Tysiąclecia Stefan Kardynał Wyszyński i święty Jan Paweł II. Wiara ich polegała na obecności Bożej w Maryi i na szczególnej łasce jakiej Bóg Jej udziela, a także w pobożności wierzących. Kultu Bogarodzicy nie można zrozumieć bez odwołania się do Tradycji. Królewskie Śluby w niebywały sposób podniosły znaczenie Jasnej Góry. Tytuł „Królowa Polski” został powiązany z Jasnogórską Ikoną Matki Bożej. Świadczą o tym insygnia królewskie, które zostały umieszczone przy obrazie Matki Bożej w 1926 r. ${ }^{39}$ Obserwujemy maryjny charakter polskiej kultury w budowanie tożsamości narodowej, a kult maryjny stał się dominujący w polskiej kulturze.

\section{Kardynał Prymas Tysiąclecia „wszystko postawił na Maryję” - idziemy do Chrystusa przez Maryję}

Wyszyński w najtrudniejszym czasie dla Polski wszystko postawił na Matkę Bożą. W trzyletnim więzieniu w Stoczku Warmińskim powstała idea oddania Narodu w macierzystą niewolę Maryi za wolność Kościoła w Polsce i na świecie. 8 grudnia 1953 r. stał się Niewolnikiem Matki Jasnogórskiej, której służył: „Niewolnik oddany Jej w więzieniu w Stoczku Warmińskim, dnia 8 grudnia 1953 roku, najpokorniej proszę, Ucieczkę Grzeszników, aby była mi Orędowniczką przed Tronem Trójcy Świętej. Amen”. Tak kończy swój testament Kardynał Wyszyński, podpisując się jako Niewolnik Maryi (15 sierpnia 1969 r. $)^{40}$. Odtąd całe jego życie było przeniknięte rysem maryjnym ${ }^{41}$. Prymas

\footnotetext{
39 Por. A. Szafrański, „Z dawna Polski Tyś Królową, „Ateneum Kapłańskie” 1988, nr 476, s. 77.

40 Por. S. Wyszyński, Głos Jasnej Góry, Warszawa 1986, s. 478.

4114 lutego 1953 r. w obecności dwojga współpracowników S. Wyszyński dokonał osobistego aktu zawierzenia Maryi. „W pewnym momencie podczas Mszy św. twarz Księdza Prymasa rozpromieniła się przedziwnym światłem, radością i pokojem”. Prymas po Mszy św. powiedział: „Dziś wszystko postawiłem na Maryję”. W czasie modlitwy błagał: „Maryjo, widzisz, co się dzieje z Kościołem Twojego Syna! Uratuj
} 
przygotowywał się przez 3 tygodnie do złożenia aktu całkowitego oddania się w niewolę Maryi, według wskazań św. Ludwika Marii Girgnion de Montfort, a przez Jej ręce w całkowitą Chrystusową niewolę ${ }^{42}$. Oddanie siebie w niewolę Maryi jest źródłem prawdziwej wolności ${ }^{43}$.

Inspiracją jego działalności był prymas A. Hlond. Po jego śmierci Wyszyński „uczynił własnym maryjny testament swego Poprzednika. Wszystko postawił w Polsce na Matkę Najświętszą. Osobiście zaufał Maryi i czynił wszystko, aby to czego Prymas Hlond nie zdążył dokonać było dokonane" ${ }^{\prime 4}$. Prymas rósł razem z Matką Bożą ${ }^{45}$. Świadectwem są jego słowa: „Przez dwadzieścia pięć lat mojego pasterzowania (prymasostwa) wszystko przeprowadzałem $\mathrm{z}$ pomocą Bogurodzicy Dziewicy, Bogiem sławionej Maryi, tej, co Jasnej broni Częstochowy $(. . .)^{46}$. „Drogę tę uważam za najlepszą cząstkę, którą Bóg pozwolił mi obrać. Pragnąłbym, aby nigdy nie była odebrana"47. Maryja dla Prymasa jest Matką Chrystusa i Kościoła na sposób osobowy. Maryja jest pełną godności Służebnicą Pańską, żyjącą w nieustannej komunii z Bogiem, „pełną łaski”. Prymas odwoływał się do Macierzyństwa Maryi ${ }^{48}$. Jej macierzyństwo pełne opieki to jakby duchowy płaszcz, pod którym można się schronić przed niebezpieczeństwem. Indywidualna pobożność maryjna Kardynała rozszerzała

go. Pomóż mi, pomóż (...)", http://centrumzawierzenia.jasnagora.pl/wp-content/ uploads/Przez-Akt-Oddania.pdf, s. 68.

42 Por. tamże, s. 72.

${ }^{43}$ Na odwiecznych drogach oddawania się w niewolę (Warszawa, kościót Św. Stanisława, 5.04.1965 r.), KP 20, 44. Matka, 58.

44 Por. J. Pach, Droga maryjna Tysiąclecia, „Znaki Czasu. Kwartalnik Religijno-Społeczny” 1987, nr 7/3, s. 114.

45 „Ogromne poświęcenie dla innych widzimy w Matce, która naraża się na śmierć, aby przekazać nowe życie rodzinie narodowi i ludzkości (...)”, „Cokolwiek dzieje się w Kościele Bożym w Ojczyźnie naszej - Tobie to zawdzięczamy”, S. Wyszyński, Homilia (Jasna Góra, 25.08.1960 r.). Zob. stara.radiomaryja.pl (dostęp: 09.09.2016 r.).

46 S. Wyszyński, Wszystko postawiłem na Maryję, Warszawa 1998, s. 19.

47 Przezakt oddania do zawierzenia Maryi w Trzecim Tysiącleciu, red. Z. S. Jabłoński, Jasna Góra-Częstochowa 2004, s. 25.

48 Por. tamże, s. 242-243. 
się w wymiar społeczny życia narodowego i kościelnego. Oddanie w niewolę Maryi zostało złożone, a jego zewnętrznym wyrazem były dwa dokumenty milenijnego Aktu Oddania Polski, podpisane przez biskupów. Jeden w srebrnej tubie umieszczono przy obrazie Jasnogórskim, a drugi przekazano Pawłowi VI. Papież uznał ten akt, obok chrztu Mieszka I, za najwyższej rangi w życiu Narodu Polskiego ${ }^{49}$. W życiu Kardynała „kult Matki Boga nie wynikał jedynie z tradycji rodzinnej czy ojczystej, ale opierał się na podstawowych prawach Objawienia"50. Postrzeganie Maryi w rodzicielskim zadaniu to osobiste doświadczenia Prymasa już z czasów dzieciństwa. Wyznał „Cześć moja do Matki Najświętszej rozwijała się powoli” ${ }^{51}$. Miała na nią duży wpływ m.in. myśl mariologiczna teologa ks. Karola Journeta ${ }^{52}$. Jednak przełomowym momentem jego maryjności był czas aresztowania przez władze komunistyczne ${ }^{53}$. W więzieniu powstała idea odnowienia Ślubów Królewskich w trzechsetną rocznicę ich złożenia Matce Najświętszej przez Jana Kazimierza i proklamowania Maryi Królową Korony Polskiej. Jasnogórskie Śluby Narodu Polskiego, które odbyły się na Jasnej Górze 26 sierpnia 1956 r. w Uroczystość Najświętszej

\footnotetext{
49 Napisał do Prymasa, Episkopatu i Narodu Polskiego w specjalnym breve, że żaden naród w świecie chrześcijańskim nie dokonał tego, czego Polacy dokonali w czasie Millenium 3 maja 1966 r. „Zaprawdę nie mogliście wspanialej uczcić tysięcznej rocznicy owego dnia, kiedy to Polska przyjęła skarby religii chrześcijańskiej i poddała się pod najsłodsze jarzmo Chrystusa i Jego Matki (...). Bądźcie pewni, że w ten sposób katolicka Polska zostaje związana ze Stolicą Apostolską jeszcze ściślejszym węzłem i coraz głębiej zapada w serce tego, który będąc Następcą św. Piotra, zapragnął być razem $\mathrm{z}$ wami, aby wziąć osobiście udział w owych uroczystościach (...)". Tamże.

50 Por. Z. Peszkowski, Do czytelnika, w: Madonna poetów. Antologia współczesnej polskiej poezji maryjnej, Londyn 1966, s. 9.

51 E. K. Czaczkowska, Kardynał Wyszyński. Biografia, Kraków 2013, s. 246.

52 Por. J. Pach, Stefan Kardynał Wyszyński jako inicjator eklezjalnego wymiaru maryjności w Polsce, w: Sympozjum mariologiczne. Jasna Góra, 6-8.12.1993 r.; Zawierzenie Maryi ku przyszłości, red. Z. S. Jabłoński, Jasna Góra-Częstochowa 1994, s. 108 .

${ }^{53}$ Po uwolnieniu $\mathrm{z}$ więzienia prawie wszystkie kazania i wypowiedzi Kardynała były maryjną katechezą.
} 
Maryi Panny ${ }^{54}$, są z niewypełnionymi w pełni ślubami królewskimi. Są jednak od nich bardziej rozwinięte i dostosowane do potrzeb naszych czasów. Wiążą treścią swoich zobowiązań wszystkich wiernych w całym kraju. Treść ślubów uczynił kard. Wyszyński przedmiotem dziewięcioletnich rekolekcji narodowych - tzw. Wielkiej Nowenny, przygotowujących do obchodów tysiąclecia Chrztu Polski. Śluby były początkiem przygotowania narodu do Milenium Chrztu Polskiego $^{55}$. Wielka Nowenna z okazji jubileuszu 1000-lecia Chrztu Polski zakończyła się uroczystym ślubowaniem Polaków i oddaniem się w niewolę miłości Maryi, Matki Kościoła w Polsce i świecie. Legatem papieskim na tych uroczystościach został Prymas Kardynał Wyszyński. 3 maja 1966 r. Prymas Polski dokonał Aktu Oddania Narodu w macierzyńską niewolę miłości za wolność Kościoła w świecie i w Polsce ${ }^{56}$. Ślubowanie, które było preludium Nowenny, wzywało wierzących do odrodzenia indywidualnego i społecznego w dziedzinie religijno-moralnej ${ }^{57}$. Peregrynacja Maryi w kopii Jej Cudownego Obrazu, poświęconego przez papieża Piusa XII, była przygotowaniem do obchodów Millennium. W ciągu trwającej nowenny Matka Boża

54 Uroczystość odnowienia Ślubów Narodu zgromadziła milionową rzeszę wiernych. Zabrakło na niej Prymasa. Błagano na niej o uwolnienie kardynała (26 października tego roku ks. Prymas został uwolniony z więzienia). Kardynał Stefan Wyszyński po swym uwolnieniu złożył na Jasnej Górze votum dziękczynne: srebrną ozdobną tablicę z wizerunkiem Matki Bożej Częstochowskiej i wyobrażeniem dwóch katedr: Gnieźnieńskiej i Warszawskiej. Napis głosi: „Prymas Polski, Stefan Kardynał Wyszyński, uwolniony po trzech latach z więzień, dziękuje Zwycięskiej Dziewicy, Wspomożycielce, Królowej Polski za przemożną opiekę w czasach niewoli. Rychwałd Królewski - 1953, Stoczek Warmiński - 1953 - 1954, Prudnik Śląski - 1954 - 1955, Komańcza k. Sanoka - 1955 - 1956, Uroczystość Chrystusa Króla, 28 X 1956 r.” Wotum jest umieszczone nad tabernakulum pod Cudownym obrazem. Zob. P. Raina, Jasnogórskie Śluby Narodu Polskiego 1656-1956-1966, Warszawa 2006.

55

56 Akt miał podwójny cel. Oddanie narodu Maryi w niewolę Miłości oznaczało zabezpieczenie przed źle rozumianą wolnością, swawolą, skrajnym indywidualizmem. Było to także błaganie Matki Bożej o wyzwolenie z niewoli komunistycznego systemu i agresji ze strony totalitarnego Związku Radzieckiego.

57 Por. S. Wyszyński, Wszystko postawiłem na Maryję, dz. cyt., s. 118-12. 
udzieliła narodowi polskiemu wiele łask ${ }^{58}$. Kopia obrazu Jasnogórskiego, wędrująca $\mathrm{z}$ parafii do parafii, to „promień przesuwający się przez naszą ziemię" ${ }^{59}$.

Wyjątkowy charakter misji Maryi to skuteczna pomoc w osobistej drodze do świętości. Bóg uczynił Maryję pierwszym pomocnikiem w walce z szatanem ${ }^{60}$. Kardynał Wyszyński, wraz z biskupami, powołał do istnienia dzieło Pomocników Matki Kościoła. Zachęcali oni do pomagania wszędzie, „w domu, w szkole, w pracy, na ulicy, w tramwaju, w sklepie i kościele”61. Dzieło „Pomocników Matki Kościoła” rozpoczął 26 sierpnia 1969 r. od świadectwa: „Pragnę dziś otworzyć serce swoje przed Wami, aby Wam odsłonić tajemnice mocy trwania Kościoła Chrystusowego w Ojczyźnie naszej. Pragnę wam wyznać swoją wiarę w to, że tę moc trwania zawdzięczamy «obecnej w Misterium Kościoła Bogurodzicy»" ${ }^{22}$.

Maryjność Kościoła w Polsce, kierowanego przez Kardynała Stefana Wyszyńskiego, przejawiała się w takich inicjatywach, jak: Jasnogórskie Śluby Narodu złożone Królowej Polski na Jasnej Górze 26 sierpnia 1956 r. ${ }^{63}$; Dzieło Pomocników Matki Kościoła i Społeczna

58 Zanotowano wiele aktów spowiedzi po kilkudziesięciu latach. Składano także pod przysięgą zeznania o cudownych uzdrowieniach i innych otrzymanych łaskach. Zob. M. Królik, Cuda i łaski zdziałane za przyczyną Jasnogórskiej Matki Bożej dawniej i dziś, Częstochowa 2006, s. 180.

59 Prymas Stefan Wyszyński zainicjował w 1957 r. peregrynację (wędrówkę) kopii Obrazu Matki Bożej Częstochowskiej po wszystkich diecezjach w Polsce. W ten sposób rozpoczęła się wielka nowenna przed obchodami tysiąclecia chrześcijaństwa w naszym kraju. W ciągu kilkunastu lat Królowa Polski odwiedziła wszystkie parafie, uroczyście przeprowadzana z miejsca na miejsce przez tysiące osób.

60 Por. S. Wyszyński, Nadzieja na oddanie świata Matce Kościoła (Warszawa 11.06.1973 r.), nr 1238, s. 3 i 5.

${ }^{61}$ K. Wojtkiewicz, Maryjny wzorzec odnowy wiary narodu polskiego według Prymasa Stefana Wyszyńskiego, „Rocznik Skrzatuski” 2013, t. I, s. 35.

${ }^{62}$ List Prymasa Wyszyńskiego pisany na Jasnej Górze z 26 sierpnia 1969 r., w: Komisja Maryjna Episkopatu Polski, Pomocnicy Matki Kościoła, Rzym 1974, s. 13.

${ }^{63}$ Tekst ślubów został zredagowany przez Prymasa Tysiąclecia, kard. Stefana Wyszyńskiego w więzieniu, w latach 1953-56. W rocie Jasnogórskich Ślubów zawarł całe swoje doświadczenie duszpasterskie. Przebywał w Prudniku, a później 
Krucjata Miłości. Stanowiły one bezpośrednią konsekwencję milenijnego Aktu oddania, idei świętego niewolnictwa osobistego i społecznego, nawiedzenia poszczególnych parafii przez kopię jasnogórskiego obrazu, sobotnich nabożeństw Królowej Polski; różnych innych form czci Maryi Matki Kościoła i Pani Jasnogórskiej.

\section{Końcowe wnioski}

Podstawowe przesłanie: Prymas Tysiąclecia Stefan Kardynał Wyszyński prowadził Polskę drogą zawierzenia Bogu przez Maryję i cały naród skupiał pod płaszczem opieki umiłowanej Pani Jasnogórskiej. Prawdziwy zmysł prorocki kard. Wyszyński okazał w ustosunkowaniu się do kwestii społecznej. Czynił to w sposób godny wizji społecznej „nowej ewangelizacji”, choć nie używał tej nazwy. Prymas Wyszyński mówił, że „przyjdą nowe czasy, (które) wymagają nowych świateł, nowych mocy, Bóg je da w swoim czasie. Wszystko zawierzyłem Matce Najświętszej i wiem, że nie będzie słabszą w Polsce, choćby się ludzie zmieniali oraz że „Maryja (jest) drogą Boga ku człowiekowi i drogą człowieka ku Bogu”64. Polska, która w szczególny sposób czciła Niepokalaną Maryję, została obroniona przez Nią przed błędami i herezjami. Przekonanie o roli Niepokalanej w czasach dramatycznych dla Polski wyrażają obrazy znajdujące się na Jasnej Górze, przedstawiające triumf Maryi nad herezjami. Matka Boża Częstochowska jest znakiem cudownej opieki. Prymas Polski, ufając w pomoc Maryi, odważnie przeciwstawiał się władzy komunistycznej. Za swoją postawę został aresztowany. Pisał wtedy: „Obrona Jasnej Góry dziś - to obrona chrześcijańskiego ducha Narodu, to obrona kultury rodzinnej, obrona jedności serc ludzkich w Bożym Sercu. Jest to obrona swobodnego oddechu człowieka, który

w Komańczy. Zob. P. Raina, Jasnogórskie Śluby Narodu Polskiego 1656-1956-1966, Warszawa 2006, s. 22-24

${ }^{64}$ Człowiek niezwykłej miary. Ojciec Święty Jan Paweł II o kardynale Stefanie Wyszyńskim, kardynał Stefan Wyszyński o sobie, kardynał Józef Glemp o kardynale Stefanie Wyszyńskim, red. M. Plaskacz, A. Rastawicka, W. Wojdecki, Warszawa 1984, s. 119. 
chce wierzyć bardziej Bogu niż ludziom, a ludziom po Bożemu (...). Już dziś oddaję wszystkie swoje modlitwy i więzienne cierpienia ku uczczeniu Pani Jasnogórskiej - za naród Chrystusowy, by wytrwał w łasce i miłości”65. Z głębokiego poznania Boga rodzi się miłość ku Niemu i Matce Najświętszej. „Potrzebujemy Matki Bożej. Przecież nawet Bóg Jej potrzebował!”6 Bóg sprawuje opatrzność swoją nad światem, kreśli cały plan w najdrobniejszych szczegółach. Wykonanie jednak swego planu powierza człowiekowi. W tym celu przygotował Prymasa Wyszyńskiego do roli swego współpracownika, by mógł wykonać Boże zamierzenia. W ślad za kard. Wyszyńskim poszedł Karol Wojtyła, który świadomie stał na straży tak ważnych wartości. W 1966 r. Akt oddania Polski Najświętszej Maryi Panny Królowej Polski ma wybitne nadprzyrodzone znaczenie i sens. Jest to niezwykły symbol i znak. Prymas powiedział, gdy do Komańczy przyszła informacja o przebiegu uroczystości o rzeszach pielgrzymów: „Ten lud zaświadczył, że Królowa Polski jest najbardziej popularną postacią w życiu Narodu (...) Oddziaływania Jasnej Góry na życie Narodu nie da się sprowadzić do płytkiej dewocji. (...) Jasna Góra jest wewnętrznym spoidłem życia polskiego, jest siłą, która chwyta głęboko za serce i trzyma cały Naród w pokorze i mocnej postawie wierności Bogu, Kościołowi i jego hierarchii”. Pierwszym „czcicielem” Maryi, który w doskonały sposób oddał cześć swej Matce, był Jezus Chrystus. Chrystus najlepiej i najpełniej „praktykował” kult maryjny, cześć dla swej Matki. Chrystocentryczność jest niemożliwa bez Maryi. Maryja zawsze pomnaża chwałę Chrystusa, nigdy jej nie pomniejsza $^{67}$. Chrześcijaństwo w naszym narodzie zawsze odnosiło się do Chrystusa i Jego Matki. Kościół święty potrzebuje Maryi. Maryja walczy z nieprzyjaciółmi Kościoła i duszy ludzkiej i zawsze zwycięża.

\footnotetext{
${ }^{65}$ Tyś wielką chlubą naszego narodu, red. K. Kunz, Częstochowa-Jasna Góra, s. 184.

66 S. Wyszyński, Na drogach zawierzenia, Warszawa 1996, s. 68-69.

${ }^{67}$ Por. Słowo przed Msza świętą. Dzień skupienia Instytutu Prymasowskiego. Choszczówka, 08.121978 r., 03. nr 2442, s. 1-2.
} 
„Wzrost czci ku Maryi powiększa cześć Chrystusa” ${ }^{68}$. Paweł VI, cytując piękne i mądre słowa: „Niech w każdym będzie dusza Maryi, aby sławił Boga; niech w każdym będzie duch, aby radował się w Panu”, zwraca się do wszystkich, którzy pytają, na czym polega pobożność chrześcijańska - autentyczna, głęboka i maryjna ${ }^{69}$. Konkretyzację Jej osoby upatrywał w cudownym Wizerunku Jasnogórskim, jako wyraz Jej obecności i wstawienniczego działania na polskiej ziemi. W Jasnej Górze prymas Wyszyński widział centrum duchowego życia wszystkich Polaków ${ }^{70}$. Jasna Góra była miejscem wielkiego programu odnowy wiary narodu. Maryja „wybrała swój tron” w Częstochowie dzięki Władysławowi Opolczykowi, który umieścił obraz Czarnej Madonny na Jasnej Górze 9 sierpnia 1382 r. Ukoronowaniem czci Maryi przez naród były śluby króla Jana Kazimierza w 1656 r., do których nawiązywał Prymas. Przygotował program odnowy duchowej ${ }^{71}$. Odtąd naród widział w ikonie Maryi Jasnogórskiej orędowniczkę. Wzór Matki Bożej był potrzebny do odnowy moralnej narodu ${ }^{72}$.

Czy został Prymas dotknięty charyzmatem Niepokalanej? ${ }^{73}$ Odpowiedź jest jedna - wpatrzony był w Maryję, Matkę Bożą. „Maryja była zasadniczą siłą Prymasa. (...) to właśnie Maryja otwarła go na całość problematyki polskiego Kościoła, również w jego społeczno-politycznym wymiarze. Wsłuchał się w dziejowe doświadczenie Polski i w Jej przedziwne ukierunkowanie ku Jasnej Górze, dzięki czemu pozwolił ukształtować zarówno siebie, jak i Kościół polski, w szkole Dziewicy

68 List Prymasa Wyszyńskiego pisany na Jasnej Górze z 26 sierpnia 1969 r., art. cyt., s. 13.

${ }^{69}$ Paweł VI przychylając się do próśb Episkopatu Polski, ogłosił Maryję Matkę Kościoła 21 listopada 1964 r. i napisał adhortację Marialis cultus - o tym jak czcić Matkę Bożą.

70 Por. S. Wyszyński, Wszystko postawiłem na Maryję, dz. cyt., s. 105-107.

71 Por. tamże, s. 125.

72 Zob. Cz. S. Bartnik, Pedagogia narodowa Prymasa Stefana Wyszyńskiego, Lublin 2001.

${ }^{73}$ W życiorysie Kardynała odnajdujemy myśl o wstąpieniu do Paulinów. Przez częste pobyty na Jasnej Górze stał się agregowanym członkiem Zakonu Paulinów, odprawiał w więzieniu sobotnie Msze ku czci Czarnej Madonny. Zapiski w więzieniu świadczą o jego miłości i przywiązaniu do Niepokalanej. 
z Nazaretu"74. Wpisanie Maryi w historię zbawienia jest decydującym argumentem uzasadniającym pobożność maryjną Prymasa. Najważniejsze tego przejawy to: obecność Maryi w misterium Chrystusa i Kościoła, wybranie Maryi przez Boga do godności Bogarodzicy ${ }^{75}$, Jej pełne związanie z Chrystusem ${ }^{76}$ i Jego dziełem ${ }^{77}$. Prymas wskazywał na Maryję jako Matkę odnowy życia duchowego dla całego narodu polskiego ${ }^{78}$, by przez prowadzenie życia chrześcijańskiego na wzór Maryi dokonała się odnowa wiary całego narodu ${ }^{79}$. Kardynał Stefan Wyszyński został nazwany Prymasem Tysiąclecia dzięki swej wielkiej i niezłomnej postawie wiary wobec programu ateizacji narodu polskiego. To duchowy przywódca Polaków. Prymas stworzył remedium na zniewolenie Polaków przez komunizm sowiecki. Jego programem okazała się pedagogia narodowa i kościelna oparta na idei Maryi - Matki Bożej. Maryjna pedagogika narodowa Prymasa Tysiąclecia polegała na zawierzeniu całego narodu Bogu przez Maryję, która stała się ogniwem łączącym. Maryja przez swoje „fiat” umożliwiła Bogu przyjęcie natury ludzkiej i wejście w ludzki świat i w ludzką społeczność. Prymas z wielkim upodobaniem nazywał Ją „Bogu-Rodzicą" ${ }^{\text {". }}$. W Jej imię potoczyły się dzieje Polski, które można nazwać dziejami maryjnymi ${ }^{81}$. August Hlond umierając, powiedział:

\footnotetext{
74 J. Pach, Droga maryjna Prymasa Tysiąclecia, art. cyt., s. 111.

75 W czasie Zwiastowania Maryja wolą swoją otworzyła bramę nieba. S. Wyszyński, „Magnifikat”. Dzień skupienia Instytutu Prymasowskiego. Laski, 25.01.1961 r., nr 166, s. 1 .

76 Bóg Ojciec oddał Swojego Syna Maryi i co najmniej 30 lat Jego życia upłynęło w zależności od Niej. Zob. S. Wyszyński, Królowa porządku, łaski i miłości. Dzień skupienia Instytutu Prymasowskiego w uroczystość Maryi, Królowej Wszechświata. Warszawa, 31.05 .1961 r., nr 179, s. 5.

77 Zob. S. Wyszyński, Zwiastowanie. Dzień skupienia Instytutu Prymasowskiego. Choszczówka, 25.03.1981 r., nr 2852, s. 6.

78 Por. S. Wyszyński, Kościół w służbie narodu, Rzym 1981, s. 12-15.

79

80 Por. S. Wyszyński, Wszystko postawiłem na Maryję, dz. cyt., s. 17, 22, 25, 28, 39, $45,66,68$.

${ }^{81}$ Od wzgórza Lecha, od pierwszej świątyni Wniebowzięcia, od św. Wojciecha, który uczył kochać Bogurodzicę, poprzez miłość świętych, jak Andrzeja Bobolę
} 
„Zwycięstwo, gdy przyjdzie, będzie to zwycięstwo Najświętszej Maryi Panny" ${ }^{82}$. Stefan Wyszyński będąc tego świadomy, całą nadzieję położył w Maryi: „Patrzmy spokojnie w przyszłość. Chociażby się poruszyły niebiosa i ziemia, nic to, Najmilsi, gdy Ona zwycięża i ściera głowę węża" ${ }^{83}$. „Cała ludzkość zwraca się do Tej, którą już w raju Bóg ukazał człowiekowi jako jedyną Nadzieję. Ona zetrze głowę węża”" . Prymas mówił do odważnych: „Matko - Królowo, prowadź nas do Syna Swego!” Ikony maryjne, w których znalazła wyraz prawda o wcieleniu Boskiego Logosu i o Bożym macierzyństwie, powinny być otaczane czcią wiernych, gdyż posiadają szczególny, sakralny charakter i stanowią nieocenioną pomoc dla pracy duszpasterskiej.

\section{Streszczenie}

Chrześcijaństwo w ciągu dziejów doświadczało wiele kryzysów doktrynalnych, a mimo to istnieje już przeszło dwa tysiące lat. Poważnym objawem kryzysu jest ateizm. Brakuje elementarnego pragnienia Boga i to staje się największym problemem religijnym w obecnych czasach. Cała Europa stoi dziś wobec wezwania, by opowiedzieć się na nowo po stronie Boga. Kardynał August Hlond wierzył, że nastąpi wielki triumf Serca Matki Bożej, po którym dopiero zakróluje Zbawiciel nad światem przez Polskę. „Polska ma stanąć na czele maryjnego zjednoczenia narodów”. Naród Polski posłuszny woli Zbawiciela zostaje wezwany do służebnego mesjanizmu w celu religijnego odrodzenia ludzkości. Zwycięstwo ma przyjść przez Maryję. Kardynał Stefan Wyszyński wprowadza program odnowy, zawarty w Ślubach Jasnogórskich Matki Bożej Częstochowskiej. W ślad za Kardynałem Wyszyńskim poszedł Karol Wojtyła, który świadomie stał na straży wartości moralnych.

i innych, poprzez katedry polskie i dzieje pełne triumfów, przez Śluby Królewskie i Jasnogórskie Śluby Narodu. Zob. J. Kudasiewicz, Jasnogórskie Śluby Narodu dziś, w: Królowo Polski przyrzekamy, Warszawa 2006, s. 213-219.

82 S. Wyszyński, Maryjność Wielkiej Nowenny. Przemówienie Stefana Kardynała Wyszyńskiego do Duszpasterzy Sanktuariów Maryjnych z 11 maja 1959 r., w: tenże, Głos z Jasnej Góry, Warszawa 1984, s. 97.

83 Tamże, s. 98.

84 Tamże, s. 298. 


\section{Summary}

Christianity throughout a history survived many doctrinal crises, and even though it exists for over two thousand years. A major aspect of the crisis is also atheism. There is a lack of elementary thirst for God, which recently becomes the biggest issue for the faith. The whole Europe is today called to stand on God's side. Cardinal August Hlond believed that there would be a great triumph of the Heart of Our Lady, after which the Savior will reign over the world through Poland. „Poland is to stand at the head of Mary unification of nations." What is important here is the cult of Our Lady of sanctuary at Jasna Gora. The chosen nation is also Poland. Poland is Marian since the beginning of Christianity in this area. All Polish Saints distinguished themselves by a special devotion to Our Lady. Polish nation obedient to the will of the Saviour is called to the priesthood for the religious rebirth of humanity. The victory has always come through Mary. Renewal program is included in the Jasna Gora Vows to Our Lady by Cardinal Stefan Wyszynski. In the wake of Cardinal Wyszynski went Karol Wojtyla, who consciously stood guard value.

Słowa kluczowe: kryzys, Maryja, maryjność, wybranie, Królowa Polski, ateizm, sekularyzacja, współczesność, kultura, nawrócenie, wiara, duszpasterstwo, zbawienie, Hlond, Wyszyński

Key words: crisis, Virgin Mary, devotion to Virgin Mary, election, The Queen Polish, atheism, secularism, contemporaneity, culture, conversion, wiara, ministry, salvation, Hlond, Wyszyński

\section{Bibliografia}

Bartnik Cz. S., Pedagogia narodowa Prymasa Stefana Wyszyńskiego, Lublin 2001.

Brzezińska R., Ku zwycięstwu. Rzecz o kardynale Auguście Hlondzie, Ząbki 2004.

Buczek J., Bóg Ojciec a Maryja w pieśniach zamieszczonych w Śpiewniku kościelnym ks. J. Siedleckiego, „Salvatoris Mater” 1999, nr 3, s. 81.

Celakówna R., Wyznania z przeżyć wewnętrznych, red. W. Kubik, Kraków 2007.

Czaczkowska E. K., Kardynał Wyszyński: biografia, Kraków 2013.

Człowiek niezwykłej miary. Ojciec Święty Jan Paweł II o kardynale Stefanie Wyszyńskim, kardynat Stefan Wyszyński o sobie, kardynał Józef Glemp 
o kardynale Stefanie Wyszyńskim, red. M. Plaskacz, A. Rastawicka, W. Wojdecki, Warszawa 1984.

Dobrzycki K. Z., Dziecko Boże Rozalia Celakówna, t. 3, Skawina 2005.

Emmerich A. K., Żywot i Bolesna Męka Pana Naszego Jezusa Chrystusa i Najświętszej Matki Jego Maryi wraz z Tajemnicami Starego Przymierza według widzeń błogosławionej Anny Katarzyny Emmerich, t. I, Wrocław 2005, s. 28-79; https://katolikintegralny.wordpress.com/2016/01/09/ papiestwo-w-wizjach-katarzyny-emmerich-oraz-marie-julie-jahenny/ (dostęp: 30.07.2016 r.).

Hlond A., W stużbie Boga i Ojczyzny. Wybór pism i przemówień 1922-1948, red. St. Kosiński, Warszawa 1988, s. 69-79.

Jabłoński S., Wokół koronacji Cudownego Obrazu diademami św. Piusa X, w: Z Maryją Królowa Polski bądźmy świadkami miłości. Dziś i jutro, Jasna Góra-Częstochowa 2010, s. 119.

Jan Paweł II, Redemptoris Mater. Encyklika o Błogosławionej Maryi Dziewicy w życiu pielgrzymującego Kościoła, Wrocław 1995.

Katechizm Kościoła Katolickiego, Poznań 1994.

Królik M., Cuda i łaski zdziałane za przyczyna Jasnogórskiej Matki Bożej dawniej i dziś, Częstochowa 2006.

Kudasiewicz J., Jasnogórskie Śluby Narodu dziś, w: Królowo Polski przyrzekamy, Warszawa 2006, s. 213-219.

List Prymasa Wyszyńskiego pisany na Jasnej Górze z 26 sierpnia 1969 r., w: Komisja Maryjna Episkopatu Polski, Pomocnicy Matki Kościoła, Rzym 1974, s. 13.

Maria Immaculata. 150. rocznica ogłoszenia dogmatu o Niepokalanym Poczęciu NMP, red. J. Marecki, L. Rotter, Kraków 2004, s. 162-170.

Mastalska D., Maryja wzorem i nauczycielka w nauczaniu Jana Pawła II, „Salvatoris Mater” 2003, nr 3, s. 90-104.

Nowak J., Maryja w liturgii i pobożności Kościoła, Poznań 2009.

Pach J., Droga maryjna Prymasa Tysiąclecia, „Znaki Czasu. Kwartalnik Religijno-Społeczny" 1987, nr 7/3, s. 111.

Pach J., Stefan Kardynał Wyszyński jako inicjator eklezjalnego wymiaru maryjności w Polsce, w: Zawierzenie Maryi ku przyszłości. Sympozjum mariologiczne. Jasna Góra, 6-8.12.1993 r., red. Z. S. Jabłoński, Jasna Góra-Częstochowa 1994, s. 108.

Peszkowski Z., Do czytelnika, w: Madonna poetów. Antologia współczesnej polskiej poezji maryjnej, Londyn 1966, s. 9. 
Pius IX, Ineffabilis Deus. List apostolski o Niepokalanym Poczęciu Najświętszej Maryi Panny, Niepokalanów 2003.

Przez akt oddania do zawierzenia Maryi w Trzecim Tysiacleciu, red. Z. S. Jabłoński, Jasna Góra-Częstochowa 2004, s. 25.

Raina P., Jasnogórskie Śluby Narodu Polskiego 1656-1956-1966, Warszawa 2006, s. 22-24.

Ryszka Cz., Jubileusz zwycięskiej obrony Jasnej Góry. 350-lecie potopu, „Niedziela" 2004, nr 49, s. 8.

Słowo przed Msza święta. Dzień skupienia Instytutu Prymasowskiego. Choszczówka, 08.12.1978, 03. nr 2442, s. 1-2.

Szafrański A., „Z dawna Polski Tyś Królową”, „Ateneum Kapłańskie” 1988, nr 476, s. 77.

Tomziński J., Modzelewski Z., Szumska D., Panno Święta, co Jasnej bronisz Częstochowy, red. J. Tomziński, Z. Modzelewski, D. Szumska, Paryż 1981. Tyś wielką chlubq naszego narodu, red. K. Kunz, Częstochowa-Jasna Góra, s. 184.

Wojtkiewicz K., Maryjny wzorzec odnowy wiary narodu polskiego wedtug Prymasa Stefana Wyszyńskiego, „Rocznik Skrzatuski” 2013, t. I, s. 35; www.katolik.pl. (dostęp: 06.04.2016 r.).

Wyszyński S., „Magnifikat”. Dzień skupienia Instytutu Prymasowskiego. Laski, 25.01.1961 r., nr 166, s. 1.; http://centrumzawierzenia.jasnagora.pl/ wp-content/uploads/Przez-Akt-Oddania.pdf(dostęp: 10.10.2016 r.).

Wyszyński S., Homilia (Jasna Góra, 25.08.1960 r.), stara.radiomaryja.pl (dostęp: 09.09.2016 r.).

Wyszyński S., Kościół w służbie narodu, Rzym 1981.

Wyszyński S., Królowa porządku, łaski i miłości. Dzień skupienia Instytutu Prymasowskiego w uroczystość Maryi, Królowej Wszechświata. Warszawa, 31.05.1961 r., nr 179, s. 5.

Wyszyński S., Maryjność Wielkiej Nowenny. Przemówienie Stefana Kardynała Wyszyńskiego do Duszpasterzy Sanktuariów Maryjnych z 11 maja 1959 r., w: tenże, Głos z Jasnej Góry, Warszawa 1984, s. 97, 219.

Wyszyński S., Na drogach zawierzenia, Warszawa 1996.

Wyszyński S., Nadzieja na oddanie świata Matce Kościoła (Warszawa, 11.06.1973 r.), nr 1238, s. 3 i 5.

Wyszyński S., Wszystko postawiłem na Maryję, Warszawa 1998.

Wyszyński S., Z homilii wygłoszonej 2 lutego 1981 r. w Gnieźnie, www.nonpossumus.pl/nauczanie/1005.php (dostęp: 10.01.2016 r.). 
Wyszyński S., Zwiastowanie. Dzień skupienia Instytutu Prymasowskiego. Choszczówka, 25.03.1981 r., nr 2852, s. 6.

Danuta Stasiak - doktorantka teologii kultury na UKSW, mgr teologii PWT sekcja św. Jana Chrzciciela; praca magisterska pt. „Tajemnica Odkupienia w świetle „Dzienniczka” św. Faustyny Kowalskiej”. Studia podyplomowe z zakresu Zarządzania Kulturą oraz Edukacji Medialnej i Dziennikarstwa UKSW; podyplomowe studia Laboratorium Reportażu na UW (dyplom 2014 r.); doświadczenie w pracy fotografa, nauczyciela religii; zainteresowania naukowe: teologia kultury, reportaż i fotografia prasowa. Członek LinkedIn. 